\title{
没水型鉛直板近傍の波浪流に関する基礎研究 FUNDAMENTAL STUDY ON WAVE-INDUCED CURRENT NEAR SUBMEARGED WALL
}

\author{
落合 実 $^{1} \cdot$ 鈴木 功 $^{2} \cdot$ 遠藤茂勝 ${ }^{3}$ \\ Minoru OCHIAI, Isao SUZUKI and Shigekatsu ENDO \\ '正会員 工修 日本大学講師 生産工学部土木工学科（テ275-8575 千葉県習志野市泉町一丁目二番一号） \\ 2学生会員 日本大学大学院生産工学研究科（２２75-8575 千葉県習志野市泉町一丁目二番一号） \\ ${ }^{3}$ フェロー会員 工博 日本大学教授 生産工学部土木工学科（广275-8575 千葉県習志野市泉町一丁目二番一号）
}

\begin{abstract}
A wave-induced current near submearged wall type breakwater was examined for the clarification of a dispersion system of waves energy and the preservation of sea area ecosystem. The turbulence quantity of a detailed wave-induced current was obtained by PTV measuring. The characteristics of wave-induced current, especially turbulence quantity, an instantaneous velocity and circulating range to the state of wave overtopping ware elucidated. It was found that the factor of waves energy dissipation is the interference of a return flow and incident wave in the front area of structure and be the splash with overflow and circulation by return flow in the back area.

Numerical computations were performed by using DNS method. The calculation results agree well with the experiments and the adaptability of the analysis method was confirmed.
\end{abstract}

Key Words : Wave control, vertical breakwater, submerged breakwater, PTV

\section{1. はじめに}

海岸構造物の多くは防災が主な目的であり，反射 波, 打ち上げ高, 透過波などの水位変動量に注目し て，それらを効果的に制御できる構造形式が開発さ れてきた. しかし近年では浻岸海域の環境保全, 特 に沿岸海域生物の保護・育成を図る必要性が高まり, 水位変動量に加えて沿岸域の流れ特性も考慮した構 造物が望まれている.このような目的の構造物とし ては越波や透過流が期待でき, 経済的, 景観的な有 利性を考慮すると没水構造物となる.

しかし没水構造物周辺での波変形による流れの発 生, すなわち波浪による周辺流れの内部構造に関す る検討は, 波浪エネルギーの減殺に加えて海域生物 の生活環境の確保や海域生態系の保全という観点か らも重要な課題と考えられるが，十分な検討がされ ていないのが現状である.

一方，著者らは鈶直堤構造物に波浪が入射したと きの反射波, 前面水位そして透過波などの水位変動 におよぼす堤体天端高の影響を検討するために潜堤 状態から無越波となる天端高までの重複波に関する 実験を行った. また没水板の天端上水深が入射波高 の約 $50 \%$ 程度の時, 反射率, 打ち上げ高そして透過 率などの水理量が著しい影響を受けることを既に明 らかにした ${ }^{1) 22)}$. そして潜堤を対象に水位変動量と 波浪流れの構造との関連を解明するために基本構造
モデルとして単純な没水薄板鈶直防波堤を対象に一 様水深波浪場における防波堤近傍の詳細な流速計測 を行い，入射波の特徴的なタイミングにおける波浪 流の瞬間流速特性の一部を既に報告している3).

本論では前報の結果を踏まえて流速乱れ量を主眼 とした堤体近傍の波浪流特性, そしてその内部構造 と水位変動との関連を検討することを目的としてい る. また実験結果を検証するために数值解析を行い, その適用性を検討する.

このように本研究では反射波や透過波に対して効 果的な低減機能を持ち, 加えて海域生物の生育環境 を維持・構築するために必要な海水流動が波浪流に よって効果的に励起できる波浪制御域構造物の開発 を到達目的として位置付けている.

\section{2. 水理実験手法}

実験は長さ $27.6 \mathrm{~m}$, 幅 $0.7 \mathrm{~m}$, 高さ $1.0 \mathrm{~m}$ の両面ガラス 張り 2 次元造波水槽を用い, そのほぼ中央に薄板鈶 直壁（厚さ0.6cm，鋼板製）を設置した. 堤体高: $\mathrm{hs}$ は25cm〜 $57 \mathrm{~cm}$ まで $1 \mathrm{~cm}$ 毎に任意に設定できるが既に 行った堤体高と水位変動の関係から著しい水位変動 が生じない堤体高: $\mathrm{hs} / \mathrm{h}=0.7(\mathrm{Hc} / \mathrm{h}=-0.3)$ を基本ケー スとして主に検討し, 水位変動に影響の大きい堤体 高: $\mathrm{hs} / \mathrm{h}=0.8(\mathrm{Hc} / \mathrm{h}=-0.2)$ およびhs $/ \mathrm{h}=0.9(\mathrm{Hc} / \mathrm{h}=-$ $0.1)$ に関しては局所流速を代表例として比較する. 
実験は水深: $\mathrm{h}=40 \mathrm{~cm} ， 入$ 射波波形勾配: $\mathrm{Hi} / \mathrm{L}=0.016 \sim$ 0.057 , 比水深: $\mathrm{h} / \mathrm{L}=0.067 \sim 0.167$ の規則波で行った が本論では $\mathrm{Hi} / \mathrm{L}=0.026, \mathrm{~h} / \mathrm{L}=0.12$ と $\mathrm{Hi} / \mathrm{L}=0.051$, $\mathrm{h} / \mathrm{L}=0.17$ の 2 種類の波浪に関する結果を示す. 水位 計測には容量式水位計を用い, 内部流速は P T V シ ステムにより計測する. 実験水槽, 水位計設置地点 そしてP T Vシステムの概略を図ー 1 に示す.

実験はトレーサ粒子（ナイロン 12 , 平均粒径 $1 \mathrm{~mm}$, 平均比重1.02）をほぼ均一に散布し, 水槽上面から ビデオカメラの収録周期に同期したストロボスリッ 卜光 (幅約 $60 \mathrm{~cm}$, 厚さ約 $1 \mathrm{~cm}$ )を照射させ, 側面より CCD ビデオカメラで定常波の状態を撮影する. 撮影され た画像は $1 / 30 \mathrm{sec}$ 毎にL V Dに収録され，その再生画 像を解析システム (Nexus PTV system)に入力する. この解析システムの粒子追跡手法は連続する 3 時刻 において粒子画像の形状と配置の適合度を利用する 方法)を採用している.

\section{3. 数值解析手法}

本計算で用いた基礎方程式は, 非圧縮粘性流体に対 する 2 次元の連続方程式とNavi er-Stokes運動方程 式であり, それらを式(1)〜 (3)に示す.

$$
\begin{gathered}
\frac{\partial u}{\partial x}+\frac{\partial w}{\partial z}=0 \\
\frac{\partial u}{\partial t}+\frac{\partial u^{2}}{\partial x}+\frac{\partial u w}{\partial z}=g_{x}-\frac{1}{\rho} \frac{\partial P}{\partial x}+v \nabla^{2} u \\
\frac{\partial w}{\partial t}+\frac{\partial u w}{\partial x}+\frac{\partial w^{2}}{\partial z}=g_{z}-\frac{1}{\rho} \frac{\partial P}{\partial z}+v \nabla^{2} w
\end{gathered}
$$

ここで， $x$ および $z$ は，それぞれ波の進行方向およ び鈶直方向座標軸を示す．原点は，静水面と没水鉛 直壁前面の延長線が交わる点とする. $u$ および $w$ は, それぞれ $x$ および $z$ 方向流速方向成分. $t$ は時間, $g$ は重力加速度, $\rho$ は流体密度, $P$ は圧力, $v$ は動 粘性係数, $\nabla$ はLaplace演算子である.

これら（1）～(3) の基礎方程式を用いて，一様水深 中に置かれた没水型鈶直板に波浪が衝突するときに 生じる鈶直板近傍の波浪流をD N S 法 (Di rect Numer ical Simulation)により解析する. 本計算では 基礎式を 2 次の中心差分によって空間離散化し, 自 由水面の運動解析を考慮したMAC法 (Marker And Cell Method）を非定常な水面に関してより安定した 解が得られる S M A C 法を用いる.

本数値計算において, 自由水面における境界条件 は次式を満足する.

$$
\frac{\partial \eta}{\partial t}+u \frac{\partial \eta}{\partial x}=w
$$

ここで $\eta=\eta(x, t)$ は自由表面形状関数である. そし て鈶直板表面は不透過でnon-slip条件，水路床面の 境界では不透過でslip条件としている. 解析領域は 鈶直板設置地点を中心に $x$ 方向に $\pm 1.5 \mathrm{~L}$ （L：入射 波長）， $z$ 方向には静水面を基準に- $\mathrm{h} \sim 0.5 \mathrm{~h}$ （ $\mathrm{h}$ :

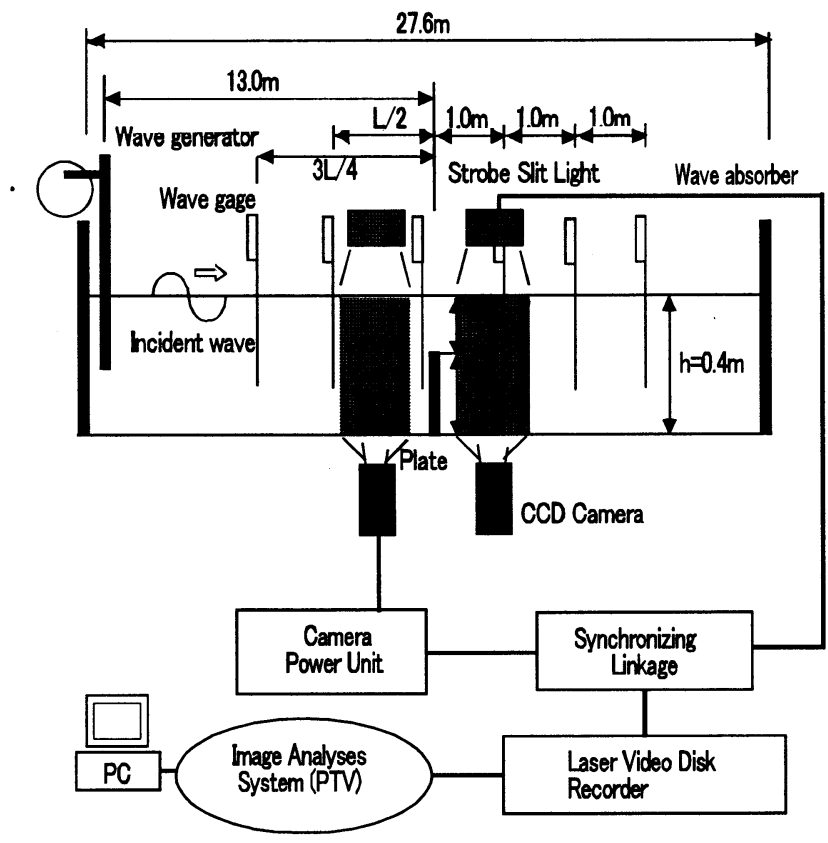

図-1 実験設備およびPTVシ人テム概略

水深）である. また計算メッシュ系はスタガード格 子を適用し，メッシュサイズは $x$ および $z$ 方向に対

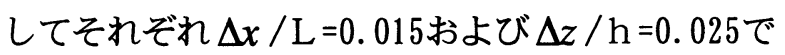
あり, 時間間隔 $\Delta t$ は解の安定性を考慮して $\Delta t=1 /$ $450 \mathrm{sec}$ とする. 計算では実験で使用した造波装置の 運動に合致した振動流速を入力している.

\section{4. 実験および数值解析結果の考察}

\section{(1)瞬間および平均流速}

図一2は波浪が没水鈶直板を越波する時の鈶直板近 傍の波浪流を測定して得られた瞬間流速べクトル分 布の一例を示したものである. 図は波浪条件 $\mathrm{Hi} / \mathrm{L}=$ $0.026, \mathrm{~h} / \mathrm{L}=0.12$ でHc/h=-0.7の天端高の場合であり, 堤体面で水位が最大となる瞬間から0.2s ec毎に一周 期の瞬間流速べクトルを示したものである.これら の図から越流する流況をまとめる.

堤体前面で最大水位となる時の前面域では入射波 の水位変動に伴う岸・下向き流れと堤体面には垂直 に衝突する流れ, 背後域では堤体を越流する岸向き の大きな流速が床面にも到達し, その到達点より堤 体側の床面で近くで沖向きの流れが生じる. その後, 前面では水位降下に伴う沖・下向き流れと堤体面で 戻り流れによる鈶直下向き流れ，そしてそれによる 堤体前面で反時計回りの循環ができる. 背後では越 流流速が小さくなり, 床面の到達点が岸側に移り, それに伴う後流が生じ, 時計回りの循環となる.

より水位が降下すると前面域では入射波の引き波 に伴う戻り流れと堤体天端からの戻り流れが, 背後 域では循舞流れが卓越する. 水位が上昇すると前面 域での水面付近での戻り流れと入射波の干渉, 堤体 直前での反時計回りの循環が生じる. また背後領域 では水面付近に中心を持った時計回りの大きな循環 となる. より水位が上昇すると前面域では, 入射波 の流れが堤体に衝突して生じる沖・上向き流速がそ 


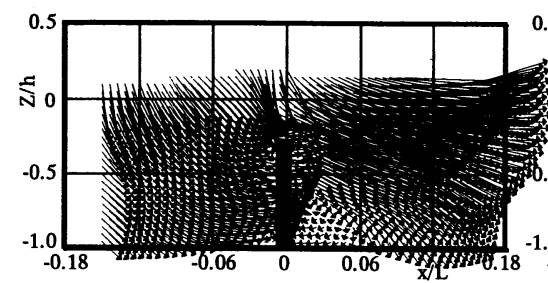

(1) $t=0 \mathrm{sec}$

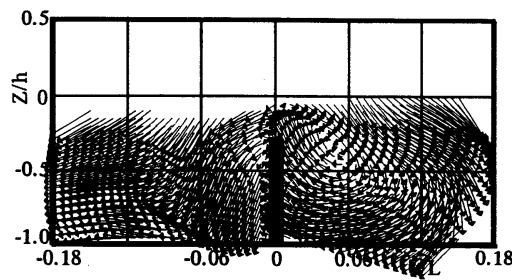

(4) $\mathrm{t}=0.6 \mathrm{sec}$

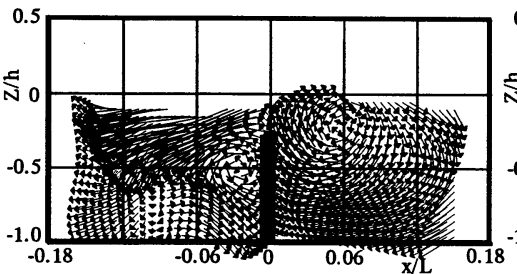

(7) $\mathrm{t}=1.2 \mathrm{sec}$

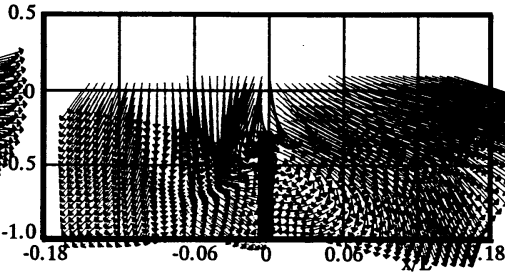

(2) $t=0.2 \mathrm{sec}$

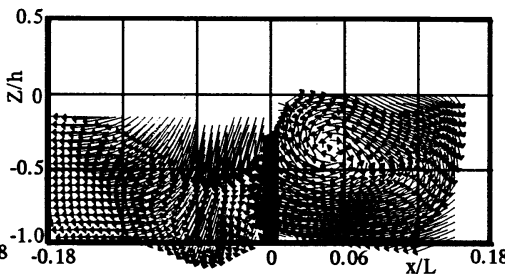

(5) $\mathrm{t}=0.8 \mathrm{sec}$

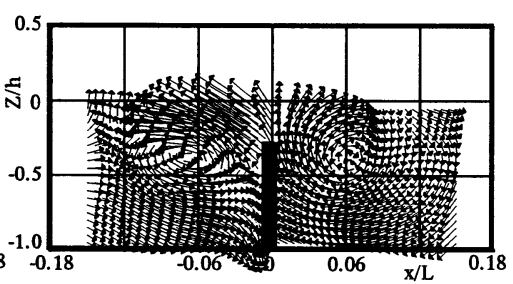

(8) $\mathrm{t}=1.4 \mathrm{sec}$

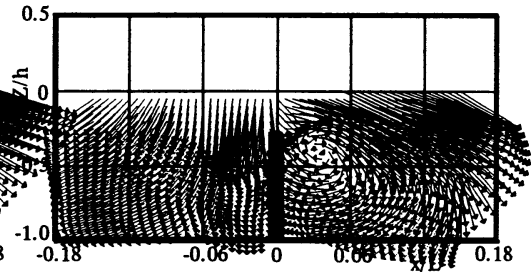

(3) $\mathrm{t}=0.4 \mathrm{sec}$

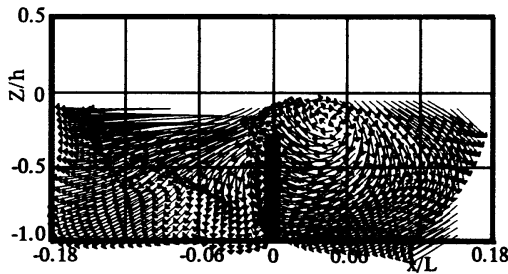

(6) $\mathrm{t}=1.0 \mathrm{sec}$

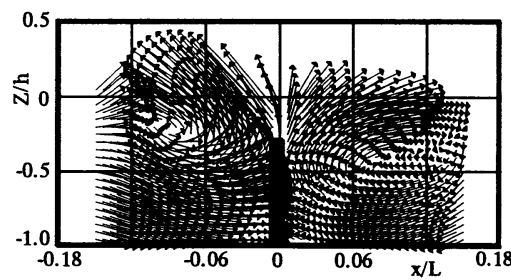

(9) $t=1.6 \mathrm{sec}$

図-2 瞬間流速分布 (実験結果; $\mathrm{Hc} / \mathrm{h}=-0.7, \mathrm{Hi} / \mathrm{L}=0.026, \mathrm{~h} / \mathrm{L}=0.12$ )

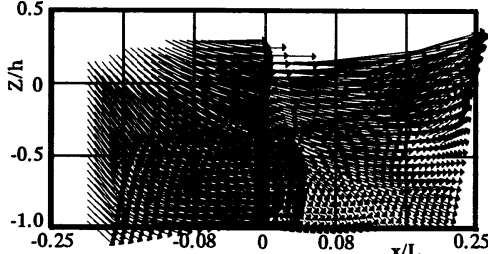

(1) $\mathrm{t}=0 \mathrm{sec}$

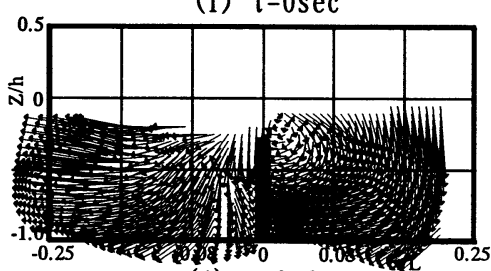

(4) $\mathrm{t}=0.6 \mathrm{sec}$

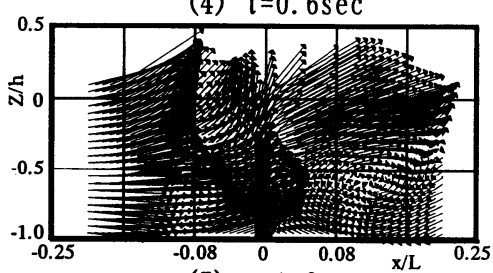

(7) $\mathrm{t}=1.2 \mathrm{sec}$

図-3 瞬間流速分布 (実験結果;

$\mathrm{Hc} / \mathrm{h}=-0.7, \mathrm{Hi} / \mathrm{L}=0.051, \mathrm{~h} / \mathrm{L}=0.17$ )

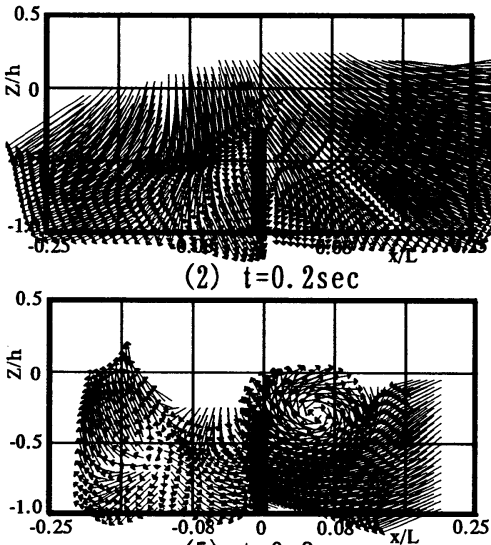

(5) $\mathrm{t}=0.8 \mathrm{sec}$

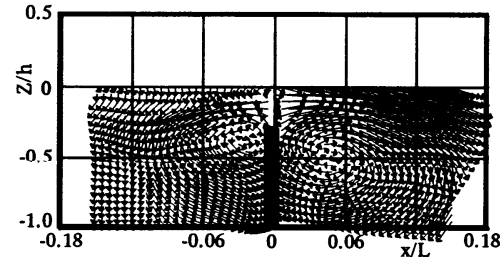

(a) $\mathrm{Hi} / \mathrm{L}=0.026, \mathrm{~h} / \mathrm{L}=0.12$

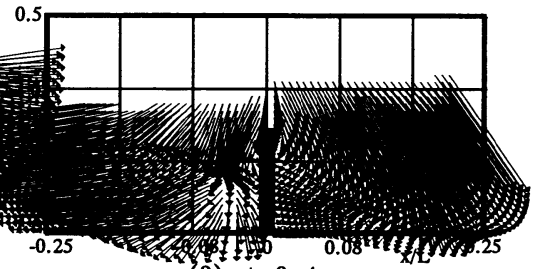

(3) $\mathrm{t}=0.4 \mathrm{sec}$

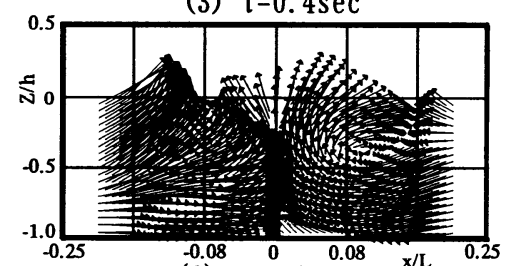

(6) $\mathrm{t}=1.0 \mathrm{sec}$

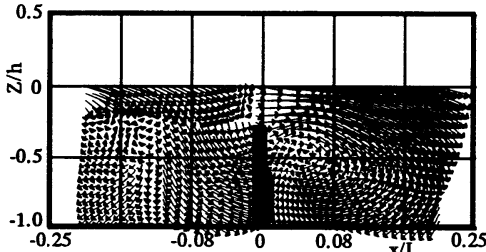

(b) $\mathrm{Hi} / \mathrm{L}=0.051, \mathrm{~h} / \mathrm{L}=0.17$

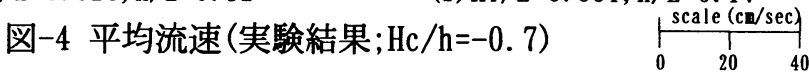

れまであった反時計回りの循環を加速させる. 背後 域では越流による流速が時計回りの循環を加速させ, その中心位置をほぼ半水深に移動する. 再び最大水 位近くになると越流が増大し, 前面域の反時計回り の循環が水面付近に移動する. 背後域の時計回りの 循環は水面からの大きな流速でその中心を床面近く に移動する. これら堤体の前面域と背後域に生じて いた循睘流れは越流が最大となる瞬間のみ消减する. 以上が堤体を波浪が越流する流況であり, 他の波
浪条件では越流と戻り流れ量の違いによって若干流 況が異なるがほぼ同様の流れ形態となっている. そ の一例を図-3に示す.これらの図から堤体前面域で は入射波と戻り流れの干渉, 背後域では越波と戻り 流れによる循環流れが特徴的な流況であり，この流 れが波浪エネルギー散逸の一要因である.

図-4は図-2および図-3の条件における一周期平均 流速であり，一波当たりの質量輸送を示す（a)にお いて前面域では堤体天端近くで反時計回りの循環, 


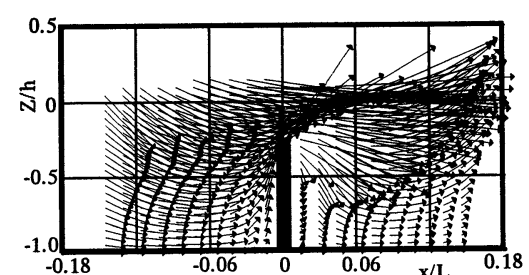

(1) $\mathrm{t}=0 \mathrm{sec}$

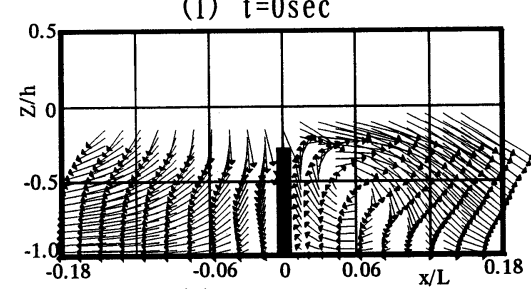

(4) $\mathrm{t}=0.6 \mathrm{sec}$

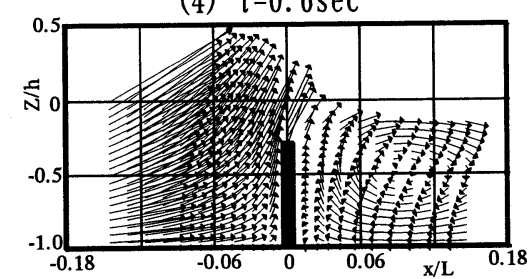

(7) $\mathrm{t}=1.2 \mathrm{sec}$

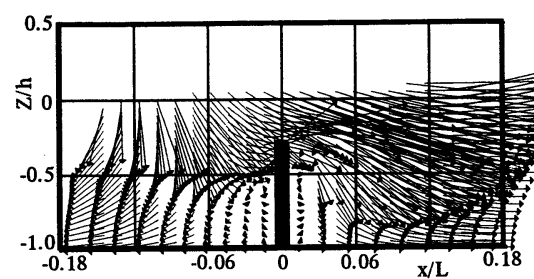

(2) $\mathrm{t}=0.2 \mathrm{sec}$

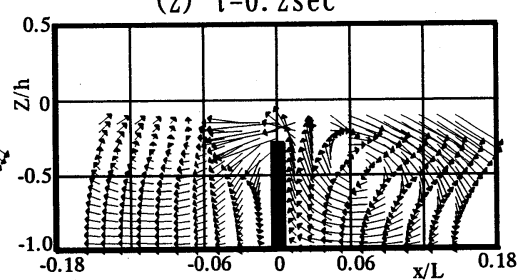

(5) $\mathrm{t}=0.8 \mathrm{sec}$

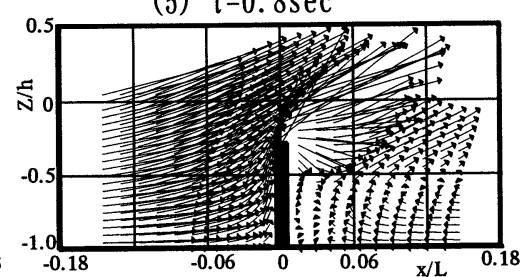

(8) $\mathrm{t}=1.4 \mathrm{sec}$

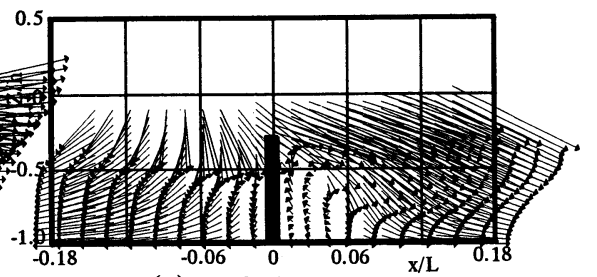

(3) $\mathrm{t}=0.4 \mathrm{sec}$

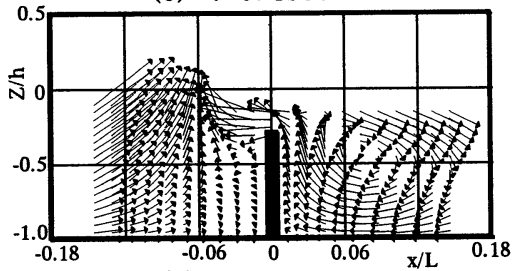

(6) $\mathrm{t}=1.0 \mathrm{sec}$,

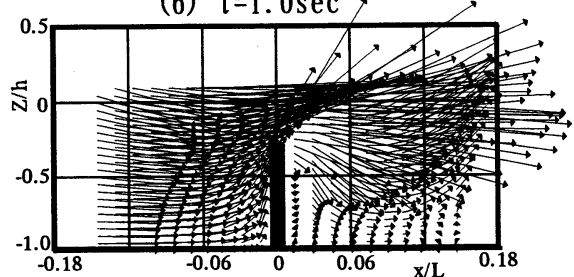

(9) $t=1.6 \mathrm{sec}$

図-5 瞬間流速分布 (計算結果; $\mathrm{Hc} / \mathrm{h}=-0.7, \mathrm{Hi} / \mathrm{L}=0.026, \mathrm{~h} / \mathrm{L}=0.12$ )

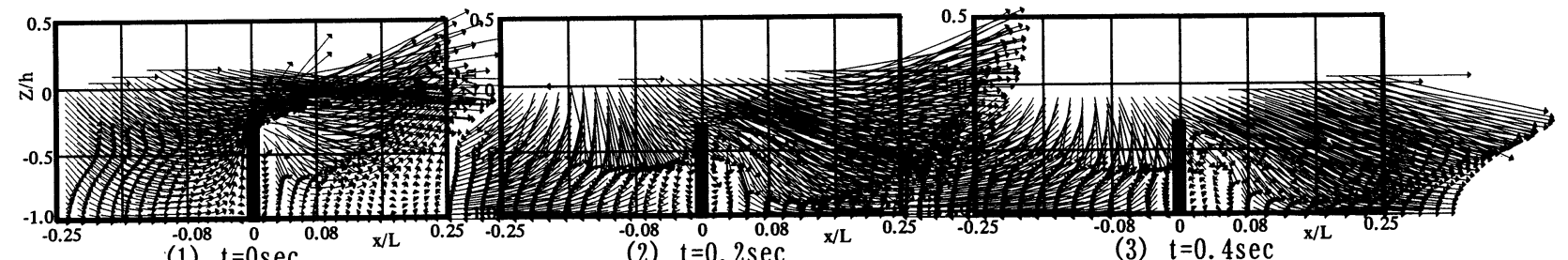

(1) $\mathrm{t}=0 \mathrm{sec}$

(2) $\mathrm{t}=0.2 \mathrm{sec}$

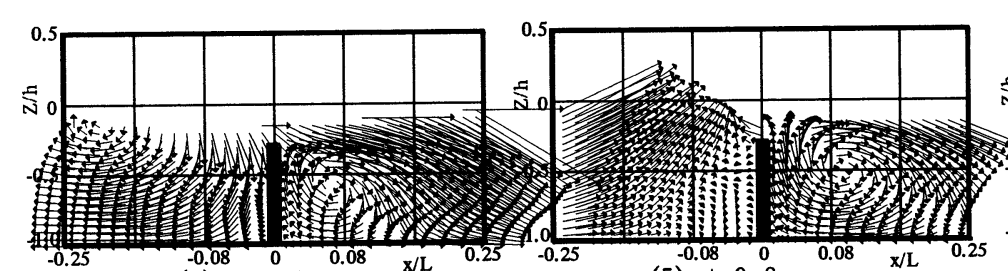

(4) $t=0.6 \mathrm{sec}$

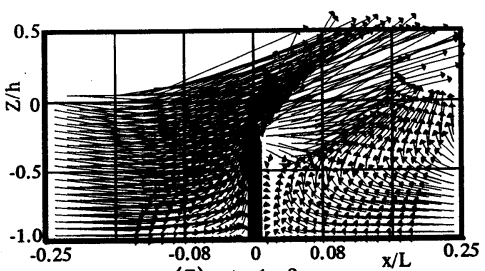

(7) $\mathrm{t}=1.2 \mathrm{sec}$
(5) $\mathrm{t}=0.8 \mathrm{sec}$

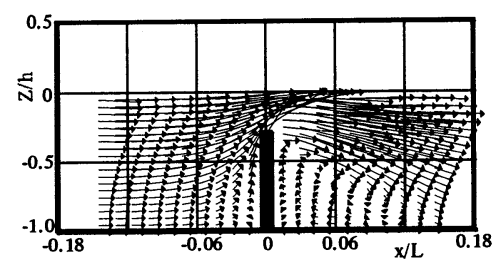

(a) $\mathrm{Hi} / \mathrm{L}=0.026, \mathrm{~h} / \mathrm{L}=0.12$

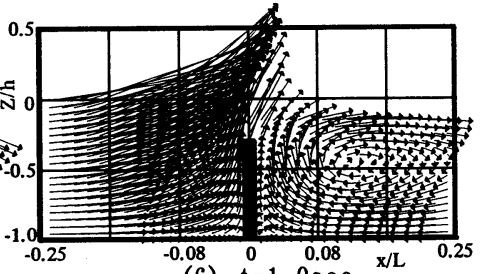

(6) $\mathrm{t}=1.0 \mathrm{sec}$

\begin{tabular}{ccc}
1 & scale (cm/sec) \\
\cline { 2 - 2 } & 1 & 40
\end{tabular}

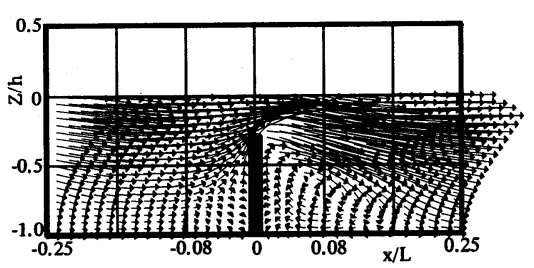

(b) $\mathrm{Hi} / \mathrm{L}=0.051, \mathrm{~h} / \mathrm{L}=0.17$

図-7 平均流速 (計算結果; $\mathrm{Hc} / \mathrm{h}=-0.7$ )

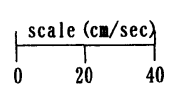

$\mathrm{Hc} / \mathrm{h}=-0.7, \mathrm{Hi} / \mathrm{L}=0.051, \mathrm{~h} / \mathrm{L}=0.17$ )

数值解析結果を示す. 図-2 と5の瞬間流速を比較する と最高水位から水位が降下し約 $0.6 \mathrm{sec}$ 程度までは計 算結果は実験結果を再現している. またそれ以後で は波の入射タイミングが実験より計算の方が早く, 岸向きの流速が戻り流れよりも大きく表現されてい る.これは堤体からの戻り流れと不連続な水面形, そして戻り流れと入射波との干渉などが局所的に生 じているためである. 一方, 背後域での時計回りの 循環流れは実験值を十分再現している.これらのこ 
とは図-3と7の関係においても認められる. そこで最 低水位から水位上昇に至るわずかな瞬間を除いた瞬 間流速の数値解析結果は実験值を十分再現しており, 本数值解析手法の有用性が認められる. また図-4と7 の平均流速を比較すると前面域において計算結果は 入射タイミングの影響による岸向きの一様な流れが 大きく, 堤体直前の複雑な実験結果と若干異なって いるが, 背後域の循睘流れはよく再現されている.

\section{(2) 流速と水位変動量の相関}

図-8は実験における反射率と透過率に対する波浪 流の相関例を示す. 図中は堤体天端近く; $x=-2 \mathrm{~cm}$, $z=-10 \mathrm{~cm}$ と $x=2 \mathrm{~cm}, z=-10 \mathrm{~cm}$ を代表点として, 一周 期当たりの鈶直流速; $w$ の変動を $\left(w_{\text {max }}-w_{\text {min }}\right) / \widetilde{w}$ で表している.ここで $w_{\text {max }}, w_{\text {min }}$ はそれぞれ $w$ の最 大と最小流速， $\widetilde{w}$ は入射波における $w$ の最大と最小 流速の差である. 図はHi/L=0.026, h/L=0.12の場合 であり, 相対天端上水深の増加と共に反射率が低下, 透過率が増大する一般的な傾向を示している．代表 地点の流速は天端上水深が小さくなるに伴い越流流 体塊の運動と合致し, 前面域で大きく, 背後域で小 さくなり, 前面水位と透過波との相関が認められる. 今後, 多くの特徴的な代表点を選定し, 種々の流速 特性量と反射率や透過率の相関を検討することによ り, 天端高パラメ-外対する流速の内部構造と水位変 動との関連が導かれるものと考えられる.

\section{（3）流速乱れ量}

図-9はHi/L=0.026, h/L=0.12の入射波が天端高 $\mathrm{Hc} / \mathrm{h}=-0.7$ の堤体を越流する場合の一周期の流速乱 れ $u^{\prime}, w^{\prime}$ を示す.ここで本論では平均流速を堤体が 無い時の堤体設置地点における入射波流速に対する 乱れ量を次のように定義する.

$$
\begin{aligned}
& u^{\prime}=\sqrt{\sum_{i=1}^{N}\left(u_{i}-\bar{u}\right)^{2}} / N \cdot \tilde{u} \\
& w^{\prime}=\sqrt{\sum_{i=1}^{N}\left(w_{i}-\bar{w}\right)^{2}} / N \cdot \tilde{u} \\
& u^{\prime} w^{\prime}=\sum_{i=1}^{N}\left(u_{i}-\bar{u}\right)\left(w_{i}-\bar{w}\right) / N \cdot \tilde{u}^{2}
\end{aligned}
$$

ここで $u^{\prime}, w^{\prime}$ は $u, w$ の乱れ量, $u^{\prime} w^{\prime}$ はレイノルズ応 力, $u_{i}, w_{i}$ は $u, w$ の瞬間流速, $\bar{u}, \bar{w}$ は入射波の $u, w$ 時系列に対する 6 次近似式による流速, $\tilde{u}, \tilde{w}$ は 入射波における $u, w$ の最大流速と最小流速の差, $N$ はデー夕数である.

岸沖方向流速 $u$ において, 前面域では堤体によっ て打ち上げ，戻り流れなどが生じる地点で比較的大 きな乱れ認められる. また背後域では水面付近と堤 体直後そして床面近くに比較的大きな乱れが生じて いる．鈶直方向流速 $w$ において，前面域では水面に 近い堤体の沖側で比較的大きな乱れとなり, 背後域

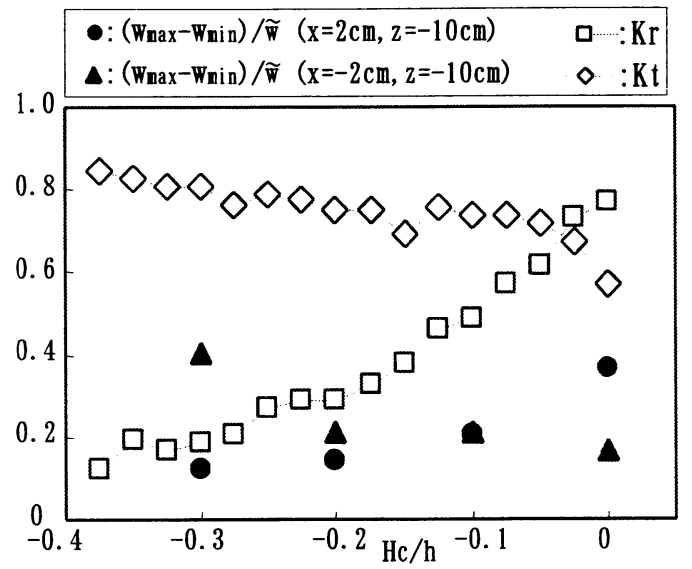

図-8 天端上水深と反射率・透過率の相関 $(\mathrm{Hi} / \mathrm{L}=0.026, \mathrm{~h} / \mathrm{L}=0.12)$
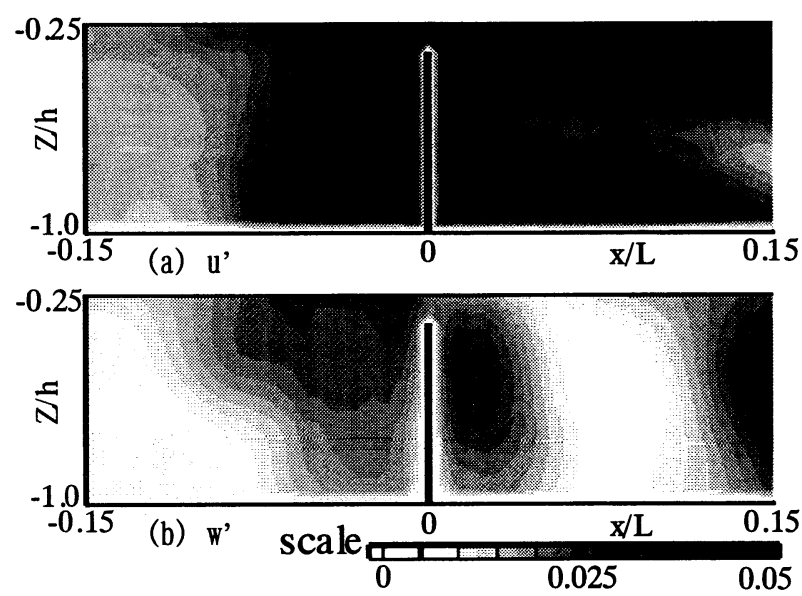

図-9 流速乱れ量; 実験結果 $(\mathrm{Hc} / \mathrm{h}=-0.7, \mathrm{Hi} / \mathrm{L}=0.026, \mathrm{~h} / \mathrm{L}=0.12)$

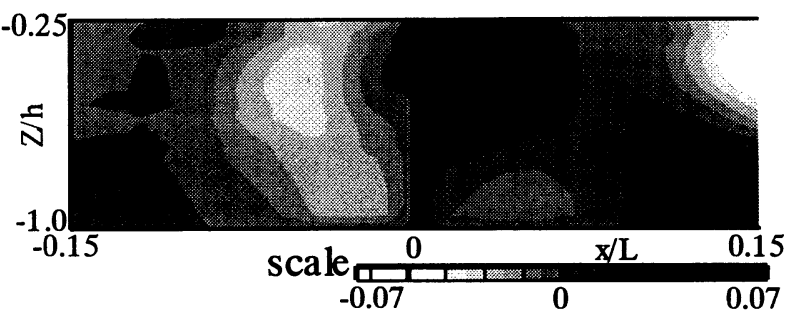

図-10 Reynolds応力u'w'; 実験結果 $(\mathrm{Hc} / \mathrm{h}=-0.7, \mathrm{Hi} / \mathrm{L}=0.026, \mathrm{~h} / \mathrm{L}=0.12)$
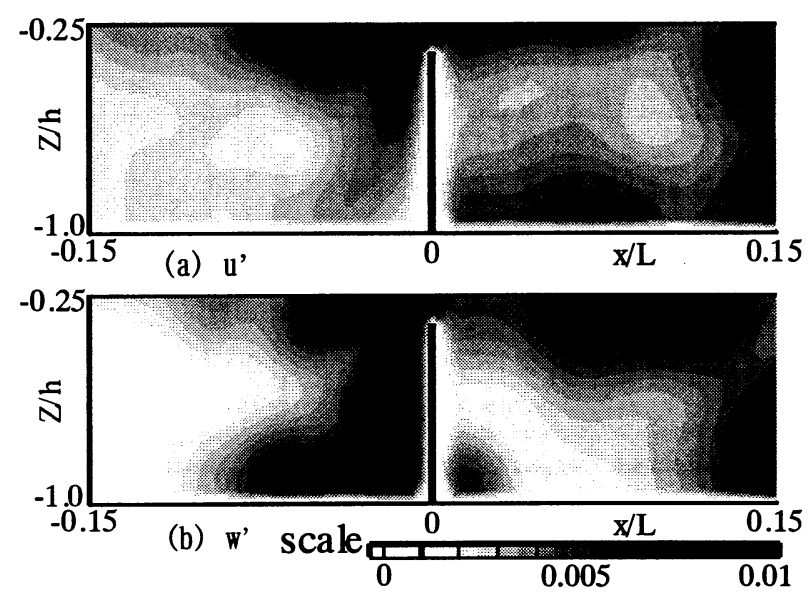

図-11 局所流速乱れ量;実験結果 $(\mathrm{Hc} / \mathrm{h}=-0.7, \mathrm{Hi} / \mathrm{L}=0.026, \mathrm{~h} / \mathrm{L}=0.12)$ 
では堤体直後で大きくなっている. 図-10は $u^{\prime} w^{\prime}$ 分 布を示す. 前面の沖側で負, 天端背後で正の比較的 大きな値となっている. 堤体からの戻り流れや越流 による天端付近でのはく離渦そして落ち込みなどが 認められる箇所で比較的大きな乱れやレイノルズ応 力が確認される.

これらの乱れは入射波に対する変動量であり，入 射波の位相変化と局所的な比較的短周期な乱れを含 んで評価している. そこでそれらを分離するために 入射波が 6 次関数で精度良く近似できることから $\bar{u}, \bar{w}$ の代わりに各点の流速時系列を 6 次関数で近 似しその関数式の值を用いて整理することとする. 図-11はその一例を示す. 図-11および9から流速乱れ は前面域において比較的短周期の乱れが堤体直前の 水面および前面部で大きく, それより若干沖側で比 較的長い周期の乱れがとなる. また背後域では比較 的短周期の乱れがほぼ全域にあり, 背後面, 水面そ して床面近くで比較的長い周期の乱れ認められる.

図-12〜14はHi/L=0.051, h/L=0.17, Hc/h=-0.7の 場合であり，それぞれ図-9〜11 と比較できる. 波形 勾配の比較的大きい図-12〜14は図-9〜11よりも平 均的に乱れ量が大きいが分布形態はほぼ同様の傾向 となっている.

\section{5. 結論}

本研究では没水型鉿直板を対象に波浪流の基本特 性を得るための水理実験と数值解析を行い, 瞬間流 速と流速乱れ量を検討した. これらの検討から次の 知見が得られた。

1)鈶直板を波浪が越流する時の構造物近傍の流速特 性, 特に瞬間流速および流速乱れ量の詳細な空間分 布が得られた。

2) 水位と瞬間流速そして平均流速分布から構造物前 面では構造物への衝突と戻り流れの干渉, 背面域で は越流と戻り流れによる循環流れの流況, そして時 系列的には越流した流体塊によって生じる渦および 戻り流れによる渦の位置と規模およびそれらが消 滅・生成される過程が明らかとなり, 波浪エネルギ 一散逸の一要因を示唆した.

3)乱れ特性量は入射波に対して比較的低周波な乱れ と比較的高周波な局所的乱れに区別し，構造物の壁 面域で大きく, 背後域では水面近傍と構造物直後そ して床面近くで大きな乱れが生じ，構造物が波浪流 に及ぼす影響範囲を明らかにした。

4) 本数值解析結果は構造物に波浪が衝突して生じる 構造物近傍の瞬間流速ベクトルの害験結果を再現で き，本数值解析手法の適応性が確認された.

以上が単純な鈶直没水板の基本特性であるが実用 的には対象地点で要望される水理条件を満足するよ うに, ここで対象とするような鈶直板を単体，ある いは複数枚設置する構造を想定している. そこで本 研究で得られた知見はその基礎データとして位置付 け, 今後は実用的な構造形式の開発に向け系統的な 検討を行いたい.
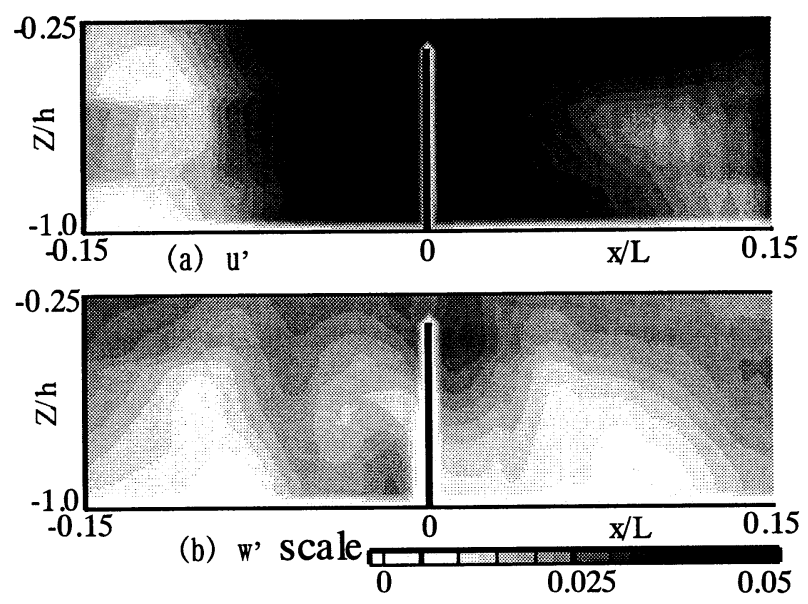

図-12 流速乱れ量;実験結果

$(\mathrm{Hc} / \mathrm{h}=-0.7, \mathrm{Hi} / \mathrm{L}=0.051, \mathrm{~h} / \mathrm{L}=0.17)$

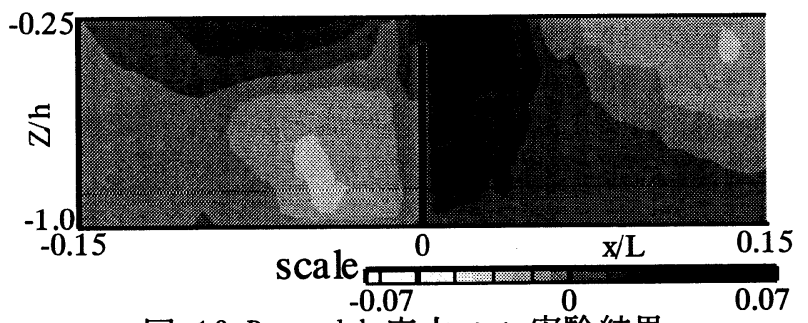

図-13 Reynolds応力u'w'; 実験結果

$(\mathrm{Hc} / \mathrm{h}=-0.7, \mathrm{Hi} / \mathrm{L}=0.051, \mathrm{~h} / \mathrm{L}=0.17)$
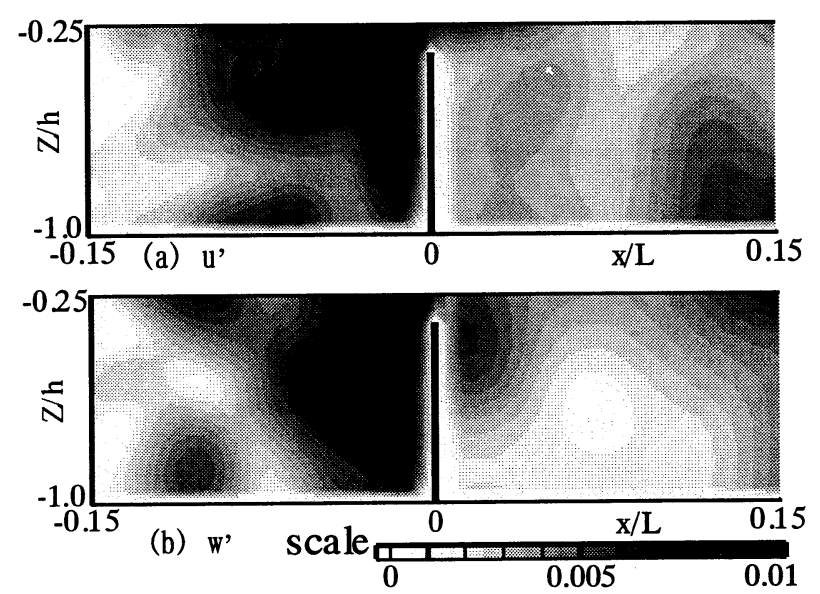

図-14 局所流速乱れ量; 実験結果

$(\mathrm{Hc} / \mathrm{h}=-0.7, \mathrm{Hi} / \mathrm{L}=0.051, \mathrm{~h} / \mathrm{L}=0.17)$

\section{参考文献}

1) 落合実, 遠藤茂勝: 鈶直壁の天端高による部分重複 波の水面変動と反射率について, 海洋開発論文集, Vol. 9, pp. 165 170, 1993

2) 落合実, 遠藤茂勝: 水面下に透過部を有する鈶直堤 の波浪制御に関する基礎実験, 海洋開発論文集, Vol. 12, pp73〜 78, 1996

3) 落合実, 遠藤茂勝: 薄鈶直堤近傍の波浪流特性に関 する実験的研究, 海洋開発論文集, V01.14, pp. 387 $\sim 392,1997$

4) 西野耕一, 笠木信英, 平田賢, 左田豊: 画像処理に 基づく流れの三次元計測に関する研究, 機械学会 論文集 (B編)，Vol. 55-501, pp405〜411，1989

(1999.4.19受付) 